\title{
Biological activities and chemical composition of crude extracts from Chresta exsucca
}

\author{
Elisandra Cristina Schinor ${ }^{1 *}$, Marcos José Salvador ${ }^{1}$, José Carlos Tomaz ${ }^{2}$, Elizabeth Mieko Furusho \\ Pral $^{3}$, Silvia Celina Alfieri ${ }^{3}$, Sérgio de Albuquerque ${ }^{4}$, Izabel Yoko Ito $^{4}$, Diones Aparecida Dias ${ }^{1,2}$
}

${ }^{1}$ Departamento de Química, Faculdade de Filosofia, Ciências e Letras de Ribeirão Preto, Universidade de São Paulo, ${ }^{2}$ Departamento de Física e Química, Faculdade de Ciências Farmacêuticas de Ribeirão Preto, Universidade de São Paulo, ${ }^{3}$ Departamento de Parasitologia, Instituto de Ciências Biomédicas, Universidade de São Paulo, ${ }^{4}$ Departamento de Análises Clínicas, Toxicológicas e Bromatológicas, Faculdade de Ciências Farmacêuticas de Ribeirão Preto, Universidade de São Paulo

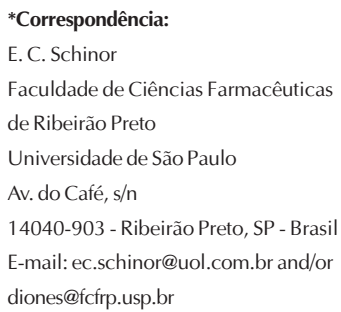

Crude extracts of Chresta exsucca were investigated for their in vitro trypanocidal, leishmanicidal, antibacterial and antifungal activities. Trypomastigote forms of Trypanosoma cruzi, amastigote-like forms of Leishmania amazonensis and twenty strains of microorganisms including Gram-positive and Gram-negative bacteria and yeasts were utilized in the bioassays. The best results were found for the leishmanicidal activity. The chemical composition of hexanic and ethanolic extracts of this species was determinate using chromatographic techniques as HRGC and HPLC-ESI-MS, respectively. Steroids, triterpenes and flavonoids were identified.

\section{Uniterms}

- Chresta exsucca

- Asteraceae

- Biological activities

- HRGC

- HPLC-ESI-MS

\section{INTRODUCTION}

The use and research of natural products have increased in the last years because of the biological activities of their constituents, including the studies performed with plants species for treatment of parasitic and microbial diseases (Kayser et al., 2003a; Newman et al., 2003; Truiti et al., 2003; Oumzil et al., 2002).

In South America, the Chagas disease is a public health problem and represents the first cause of cardiac lesions in young and economically productive adults (Moncayo, 2003). Nearly 20 million people are infected by Trypanosoma cruzi while 90 million are at risk in endemic areas (WHO, 1991, 2000). The transmission of the disease occurs mainly by the vector (Triatomine), blood transfusion and congenital routes (Coura, Castro, 2002). There is no satisfactory chemotherapy for the disease in any of its phases. The scarcity of serological control for blood donors in endemic areas and the restricted alternative of chemoprophylaxis using gentian violet, have caused a need to the development of new drugs against this disease (Araya et al., 2003; WHO, 2000).

Other problem that occurs in South America is the leishmaniases that comprise a group of cutaneous, mucocutaneous and visceral diseases caused by haemoflagellate protozoan parasites that survive and multiply in macrophages in the mammalian host and are transmitted by phlebotomine sandflies (WHO, 2000; Barata et al., 2000; WHO, 1990). The incidence of this disease has increased in the last years and therapy available mainly include antimonials, pentamidine and amphotericin B, which are toxic, difficult to apply in the field and not always effective (Peters, 1999; Thakur et al., 1999).

In addition, the development of resistant strains of pathogenic bacteria to antibiotics currently in use in the 
therapeutic is a problem of continuing concern to public health (Karaman et al., 2003).

Asteraceae family comprises many species with antimicrobial and antiprozoal activities, such as, for example, Lychnophora staavioides (Takeara et al., 2003 ) and Podolepsis hieracioides (Kayser et al., 2003b). The genus Chresta, belonging to this family, comprises 12 endemic species from Brazilian Central Plateau (Robinson, 1999). Chresta exsucca is perenial herbs adapted to the arid conditions of shrubby "cerrado" and is known principally from the state of Goiás (MacLeish, 1985). Here we report for the first time the biological activity of crude extracts from $C$. exsucca against two protozoan parasites (Trypanosoma cruzi trypomastigotes and Leishmania amazonensis amastigotes) and several strains of bacteria and fungi. The chemical composition of bioactive hexanic and ethanolic extracts was also determined by chromatographic analysis (HRGC and LC-ESI-MS).

\section{MATERIALS AND METHODS}

\section{Plant material}

Chresta exsucca was collected in Alto do Paraíso (GO-Brazil) in October 1998 and identified by Dr. João Semir (Instituto de Biologia, Unicamp, Campinas, SP-Brasil). A voucher specimen is deposited in the Herbarium of FFCLRP/USP (SPFR6873).

\section{Preparation of plant extracts}

Plant material (2100 g) was dried, pulverized and stored in dark bags to protect them from humidity and light. The powdered material was extracted by maceration with $n$-hexane, dichloromethane and ethanol at room temperature. The solvents used in each extraction were evaporated under reduced pressure and different extracts were obtained. These extracts were evaluated against Trypanosoma cruzi trypomastigote forms, Leishmania (L.) amazonensis amastigote forms, Gram-positive and Gram-negative bacteria strains and yeasts. In addition, the chemical composition of hexanic and ethanolic extracts was determined by gas chromatography and HPLC-ESIMS, using standard, respectively.

\section{Clean up procedure}

An aliquot (10 mg) of the hexane extract was resuspended in analytical grade chloroform $(3 \mathrm{~mL})$ and percolated through a sep-kap column (Alltech, silica-gel
$200 \mathrm{mg}, 3 \mathrm{~mL}$ ). The column was eluted with hexane $(10 \mathrm{~mL})$ and chloroform $(10 \mathrm{~mL})$. Fractions were collected separately and evaporated to dryness at room temperature. Chloroform phase was analyzed by HRGC in duplicate. The ethanolic extract $(10 \mathrm{mg})$ was resuspended in methanol-water $(7: 3)(3 \mathrm{~mL})$ and percolated through a sep-kap column (Alltech, C-18, $200 \mathrm{mg}, 3 \mathrm{~mL}$ ). The column was eluted with analytical grade methanol $(10 \mathrm{~mL})$ and this phase was analyzed by HPLC-ESI-MS.

\section{Gas chromatographic analysis}

Chloroform phase was analyzed by HRGC on a Hewlett-Packard model 5890 Series II Gas Chromatograph with a split injector (split ratio $1: 60$ ) at $260^{\circ} \mathrm{C}$ and a flame ionization detector at $330^{\circ} \mathrm{C}$. The injected volume was $2 \mathrm{~mL}$. Hydrogen was employed as carrier gas at an average linear velocity of $44 \mathrm{~cm} / \mathrm{s}(\mathrm{HP}-50)$ and $42 \mathrm{~cm} / \mathrm{s}$ (HP-1). The HP-50 (cross-linked 50\% phenyl-methylsilicone, $30 \mathrm{~m} \times 0.25 \mathrm{~mm} \times 0.25 \mathrm{~mm}$ ) and HP-1 (crosslinked methyl-silicone, $30 \mathrm{~m}$ x $0.25 \mathrm{~mm}$ x $0.25 \mathrm{~mm}$ ) capillary columns were employed. For HP-50 the column temperature was $280^{\circ} \mathrm{C}$ (isotherm) and for HP-1 the column temperature program was $250^{\circ} \mathrm{C}$ held for $12 \mathrm{~min}$, increased at $6{ }^{\circ} \mathrm{C} / \mathrm{min}$ to $280{ }^{\circ} \mathrm{C}$, and held this temperature for $30 \mathrm{~min}$. Data were processed on a Hewlett-Packard model 3395 injector. The standards used in the gas chromatography are listed in Table III.

\section{HPLC-ESI-MS analysis}

Ethanolic extract was analyzed by HPLC system consisting of LC10AD solvent pumps, SLC10A system controller, 7125 Rheodyne injector (Shimadzu, Japan), Shim-Pack ODC-18 analytical column $(4,6$ x $250 \mathrm{~mm})$ with a RP-18 guard column (LiChrospher ${ }^{\circledR} 100,5 \mathrm{~mm}$, 4 x 4 mm, Merck, Germany). An UV detector (SPD10A, Shimadzu, Japan) set at $280 \mathrm{~nm}$ was used. The mobile phase conditions were as follows: $15 \% \mathrm{MeOH}$ at $0 \mathrm{~min}$, $75 \%$ at $40 \mathrm{~min}$, held constant until $45 \mathrm{~min}, 15 \%$ at $60 \mathrm{~min}$. The next sample was injected after a further $10 \mathrm{~min}$. The flow-rate was $1 \mathrm{~mL} \mathrm{~min}^{-1}$, at room temperature, and the injection volume was $20 \mathrm{~mL}$. The ESI-MS spectra were acquired in a Quattro LC quadrupole mass spectrometer fitted with a electrospray interface operating in the negative ion mode (Micromass, United Kingdom). The source and desolvation temperatures were $70{ }^{\circ} \mathrm{C}$ and $100{ }^{\circ} \mathrm{C}$, respectively. Cone voltage was $30 \mathrm{~V}$. The parent ion and the retention time were compared with previously isolated standards. 


\section{In vitro trypanocidal activity}

For the trypanocidal activity blood of Swiss albino mice infected with $T$. cruzi (Y strain) was used. It was collected by cardiac puncture at the peak of parasitemia and was diluted to contain $10^{6}$ trypomastigotes $/ \mathrm{mL}$. Stock solutions (crude extracts) were prepared in $2.5 \%$ of dimethyl sulfoxide (DMSO) and were added to blood samples to provide a final concentration of $4000 \mathrm{mg} / \mathrm{mL}$. After incubation for 24 hours at $4{ }^{\circ} \mathrm{C}$, the number of parasites was determined according to Brener (1962). In the tests, gentian violet $(250 \mathrm{mg} / \mathrm{mL})$ was used as positive control and DMSO $2.5 \%$ as negative control. All experiments were performed in triplicate.

\section{In vitro leishmanicidal activity}

Axenic L. (L.) amazonensis (strain designation MPRO/BR/72/M 1841) amastigotes were serially cultivated at $33{ }^{\circ} \mathrm{C}$ in modified UM-54 mediun (Pral et al., 2003) and were used at the beginning of the stationary phase. Washed parasites were resuspended in RPMI-1640 medium supplemented with $4 \%$ fetal calf serum, $\mathrm{pH} 5.0$ and incubated at $33{ }^{\circ} \mathrm{C}$ for 24 hours with crude extracts (1000 mg/mL) dissolved previously in RPMI-1640. As controls, parasite suspensions were incubated in RPMI alone or RPMI containing 0.1\% DMSO. Amastigote viability was assessed colorimetrically by reduction of a tetrazolium salt (MTT) as described by Mosmann (1983). Amphotericin B $(20 \mathrm{mg} / \mathrm{mL})$ was used as the positive control and DMSO/RPMI-1640 (1:99) negative control. The experiments were carried out in triplicate.

\section{Antimicrobial activity}

The effect of crude extracts was evaluated against twenty strains of microorganisms, including Gram-positive and Gram-negative bacteria and yeasts. The following microorganisms were used: Escherichia coli-ATCC 10538; Pseudomonas aeruginosa - ATCC 27853; P. aeruginosa - 290 D (field strain); Micrococcus luteus ATCC 9341; Staphylococcus aureus - ATCC 25923 and 6538; S. aureus 7+ penicilinase producer; S. aureus 8penicilinase non-producer; Staphylococcus epidermidis 6epi and epiC (field strain); Candida albicans - ATCC 1023; C. albicans cas and Candida tropicalis ct (field strains), cultivated for 24 hours at $37^{\circ} \mathrm{C}$ in Mueller Hinton broth (Difco) - MHb; Enterococcus faecalis - ATCC 10541; Streptococcus mutans - ATCC 25175; S. mutans (strains 11.1; 9.1; fab3; 11.2) and Streptococcus sobrinus 180.3 (field strains), incubated for 24 hours at $37^{\circ} \mathrm{C}$ in
Brain Heart Infusion (Difco) - BHI. The standard and field strains (oral cavity) were collected from "Departamento de Análises Clínicas, Toxicológicas e Bromatológicas, Faculdade de Ciências Farmacêuticas de Ribeirão Preto, Universidade de São Paulo, Ribeirão Preto - SP, Brasil". Sensitivity tests were performed by a modified agar-well diffusion method (well technique in double layer) according to Okeke et al. (2001), Cole (1994), Grove, Randall (1955). The Mueller Hinton Medium (Difco) - MH agar plates, containing an inoculum size of $10^{6} \mathrm{cfu} / \mathrm{mL}$ of Escherichia, Pseudomonas, Micrococcus, Staphylococcus and Candida strains or $10^{6} \mathrm{cfu} / \mathrm{mL}$ of Enterococcus and Streptococcus strains on Brain Heart Infusion Agar (Difco) - BHIa plates, were used. The inoculum size of each test strain was standardized according to National Committee for Clinical Laboratory Standard (NCCLS, 1993). Subsequently, aliquots of $20 \mathrm{~mL}$ of each test-drug solution were applied into $5.0 \mathrm{~mm}$ diameter wells. Crude extract solutions were prepared at $5000 \mathrm{mg} / \mathrm{mL}$ in propyleneglycol/sterile water (5:95). After incubation at $37^{\circ} \mathrm{C}$ for 24 hours, the inhibition zone corresponding to the halo $(\mathrm{H})$ formed from well edge to the beginning of the region of microbial growth was measured in millimeters $(\mathrm{mm})$. In the tests, bacitracine $(0.2 \mathrm{UI} / \mathrm{mL})$ and ketoconazole $(100 \mathrm{mg} / \mathrm{mL})$ were used as positive controls and propyleneglycol/sterile water (5:95) served as negative control. The experiments were performed in duplicate for each strains analyzed.

\section{RESULTS AND DISCUSSION}

The results of bioactivity of crude extracts from $C$. exsucca for activity against $T$. cruzi trypomastigotes and L. amazonensis amastigote-like stages are showed in Table I. When examined against $T$. cruzi trypomastigotes, hexanic extract from C. exsucca (total plant) given at 4000 $\mathrm{mg} / \mathrm{mL}$ did not interfere appreciably with parasite viability, whereas dichloromethanic and ethanolic extracts reduced parasite viability to 46.7 and $49.2 \%$, respectively. In these assays mice infected blood containing $2.5 \%$ of DMSO were used as negative control and did not interfere with $T$. cruzi tryposmastigotes viability, while the gentian violet at $250 \mathrm{mg} / \mathrm{mL}$ were used as positive control and showed $100 \%$ of activity.

On the other hand, all the extracts evaluated interfere markedly with viability of $L$. amazonensis amastigotes. Hexanic, dichlorometanic and ethanolic extracts were clearly leishmanicidal and parasite viability were reduced to $1.8,4.7$ and $0.2 \%$, respectively. Amphotericin B $(20 \mathrm{mg} / \mathrm{mL})$, here used as a positive control, reduced amastigote viability to $3.7 \%$. Suspensions of $L$. 
TABLE I - In vitro activity of crude extracts from Chresta exsucca against Trypanosoma cruzi trypomastigotes and axenic Leishmania amazonensis amastigotes

\begin{tabular}{lcc}
\hline Extracts & \multicolumn{2}{c}{ Antiprotozoal activity $^{\mathrm{a}}$} \\
& $\begin{array}{c}\text { \% viability of } \\
\text { T. cruzi } \\
\text { trypomastigotes }\end{array}$ & $\begin{array}{c}\text { L. amazonensis } \\
\text { amastigotes }\end{array}$ \\
\hline Hexane & $89.06 \pm 0.64$ & $1.83 \pm 0.01$ \\
Dichloromethane & $46.71 \pm 1.67$ & $4.72 \pm 0.04$ \\
Ethanol & $49.15 \pm 1.46$ & $0.28 \pm 0.02$ \\
Amphotericin B & & \\
$\quad(20 \mathrm{mg} / \mathrm{mL})^{\mathrm{b}}$ & - & $3.70 \pm 0.05$ \\
DMSO/RPMI-1640 & & \\
$\quad(1: 99)^{\mathrm{c}}$ & - & $100.00 \pm 0.02$ \\
Gentian violet & & - \\
$\quad(250 \mathrm{mg} / \mathrm{mL})^{\mathrm{d}}$ & $0.00 \pm 0.00$ & - \\
DMSO $(2.5 \%)^{\mathrm{e}}$ & $100.00 \pm 0.00$ & - \\
\hline
\end{tabular}

$\mathrm{a}=$ Results expressed as $\%$ viability ( \pm standard deviation) of the $T$. cruzi trypomastigotes (extracts evaluated at $4000 \mathrm{mg} / \mathrm{mL}$ ) and L. amazonensis amastigotes (extracts evaluated at $1000 \mathrm{mg} / \mathrm{mL}) ;{ }^{b}=$ positive control of the antileishmanial assay; ${ }^{\mathrm{c}}=$ negative control of the antileishmanial assay ${ }^{\mathrm{d}}=$ positive control of the trypanocidal assay; ${ }^{\mathrm{e}}=$ mice infected blood containing $2.5 \%$ of DMSO was used as negative control of the trypanocidal assay; - = not done. amazonensis amastigotes incubated in medium alone or in medium containing $0.1 \%$ DMSO remained viable during the $24 \mathrm{~h}$ incubation period ( $\%$ amastigote viability $=100.0 \%$ ), a result that excludes spontaneous parasite damage during the bioassay.

The extracts from C. exsucca were also screened for antibacterial and antifungal activity and the results are showed in Table II. While ethanolic extract was inactive (at $5000 \mathrm{mg} / \mathrm{mL}$ ) against all eighteen strains of microorganisms tested, dichloromethanic extract was effective against only strains the Streptococcus (three strains of $S$. mutans and one strain of $S$. sobrinus) and hexanic extract inhibited the growth of five strains including $S$. aureus, $S$. mutans, $S$. sobrinus, E. coli and $P$. aeruginosa. As indicated in Table II, the extracts of $C$. exsucca assayed were ineffective against Candida strains tested. Bacitracine at $0.2 \mathrm{UI} / \mathrm{mL}$ (against bacteria strains) and ketoconazole at $100 \mathrm{mg} / \mathrm{mL}$ (against fungi strains), here were used as positive controls, inhibited the growth of all microorganism assayed. Media containing propyleneglycol/ sterile water $(5: 95)$ were used as negative control for which no inhibitory effect was observed.

The biological activities of crude extracts from $C$. exsucca are being evaluated for the first time and the results obtained indicate the potential of this plant as a source of bioactive compounds.

TABLE II - Antimicrobial activity of crude extracts from Chresta exsucca

\begin{tabular}{|c|c|c|c|c|c|}
\hline \multirow[t]{2}{*}{ Microorganisms } & $\mathrm{A}$ & B & $\mathrm{C}$ & $\begin{array}{l}\text { Bacitracine } \\
(0.2 \mathrm{UI} / \mathrm{mL})^{\mathrm{a}}\end{array}$ & $\begin{array}{l}\text { Ketoconazole } \\
(100 \mathrm{mg} / \mathrm{mL})^{\mathrm{a}}\end{array}$ \\
\hline & $\mathrm{H}$ & $\mathrm{H}$ & $\mathrm{H}$ & $\mathrm{H}$ & $\mathrm{H}$ \\
\hline S. aureus (ATCC 6538) ${ }^{\mathrm{b}}$ & - & - & - & 23 & - \\
\hline S. aureus penicilinase $+(7+)^{\mathrm{c}}$ & 12 & - & - & 25 & - \\
\hline S. aureus penicilinase $-(8-)^{c}$ & - & - & - & 25 & - \\
\hline S. epidermidis $(6 \mathrm{ep})^{\mathrm{c}}$ & - & - & - & 31 & - \\
\hline M. luteus (ATCC 9341) ${ }^{\mathrm{b}}$ & - & - & - & 25 & - \\
\hline E. faecalis (ATCC 10541) & - & - & - & 28 & - \\
\hline S. mutans (ATCC 25175) & 9 & 8 & - & 24 & - \\
\hline S. mutans $\left(\right.$ fab3) ${ }^{\mathrm{c}}$ & - & - & - & 22 & - \\
\hline S. mutans $(9.1)^{\mathrm{c}}$ & - & 10 & - & 22 & - \\
\hline S. mutans $(11.1)^{\mathrm{c}}$ & 8 & 8 & - & 22 & - \\
\hline S. mutans $(11.2)^{\mathrm{c}}$ & - & - & - & 22 & - \\
\hline S. sobrinus $(180,3)^{\mathrm{c}}$ & - & 7 & - & 23 & - \\
\hline E. coli $(\text { ATCC } 10538)^{\mathrm{b}}$ & 7 & - & - & 32 & - \\
\hline P. aeruginosa (ATCC 27853) & 11 & - & - & 22 & - \\
\hline P. aeruginosa $(290 \mathrm{D})^{\mathrm{c}}$ & - & - & - & 22 & - \\
\hline C. albicans (cas) ${ }^{\mathrm{c}}$ & - & - & - & - & 30 \\
\hline C. albicans (ATCC 1023) & - & - & - & - & 30 \\
\hline C. tropicalis $(\mathrm{ct})^{\mathrm{c}}$ & - & - & - & - & 15 \\
\hline
\end{tabular}

$\mathrm{H}=$ halo of inhibition $(\mathrm{mm}) ;-=$ absence of inhibition of microbial growth at $5000 \mathrm{mg} / \mathrm{mL} ; \mathrm{A}=$ hexane extract; $\mathrm{B}=$ dichloromethane extract; $\mathrm{C}=$ ethanol extract; ${ }^{\mathrm{a}}$ : positive control; ${ }^{\mathrm{b}}=$ standard strains; ${ }^{\mathrm{c}}=$ field strains (oral cavity). 
TABLE III - Triterpenes and sterols identified by HRGC (HP-50 colunm) in hexanic extract of Chresta exsucca

\begin{tabular}{|c|c|c|}
\hline \multirow[t]{2}{*}{ Standards } & \multirow[t]{2}{*}{$\mathrm{RR}^{\mathrm{a}}$} & \multirow{2}{*}{$\frac{\text { Hexanic extract }}{\% \text { area }}$} \\
\hline & & \\
\hline Campesterol & 1238 & - \\
\hline Stigmasterol & 1308 & 0.095 \\
\hline$\beta$-sitosterol & 1453 & - \\
\hline $\mathrm{D}^{7}$-stigmastenol & 1513 & - \\
\hline Spinasterol & 1683 & - \\
\hline Taraxerone & 1628 & - \\
\hline Epitaraxerol & 1656 & - \\
\hline Taraxerol & 1698 & - \\
\hline$\beta$-Amyrin & 1768 & 0.165 \\
\hline$\alpha$-Amyrin & 1992 & 1.335 \\
\hline Lupeol & 2052 & 1.080 \\
\hline$\beta$-Friedelanol & 2491 & - \\
\hline Friedelin & 2724 & - \\
\hline Pseudotaraxasterol & 2479 & - \\
\hline Taraxasterol & 2570 & - \\
\hline 11-oxours-12-ene & 3160 & - \\
\hline 11-oxoolean-12-ene & 3586 & 0.240 \\
\hline Taraxerol acetate & 1872 & - \\
\hline$\beta$-amyrin acetate & 1930 & 9.365 \\
\hline$\alpha$-amyrin acetate & 2154 & 29.640 \\
\hline Lupeol acetate & 2234 & 30.335 \\
\hline Bauerenyl acetate & 2508 & - \\
\hline 11a,12a-oxidetaraxeryl acetate & 2810 & - \\
\hline$\beta$-friedelanol acetate & 2871 & - \\
\hline$\alpha$-amyrinonil acetate & 3653 & 8.615 \\
\hline$\beta$-amyrinonil acetate & 4126 & 1.935 \\
\hline
\end{tabular}

Seeking to verify the chemical composition of the bioactive crude extracts from $C$. exsucca, analysis employing the chromatographic techniques HRGC and HPLC-ESI-MS was proceeded.

Gas chromatography has been the traditional technique for the analysis of terpenoids. Improved technology in GC fused-silica capillary columns has enabled the use of much shorter $(<10 \mathrm{~m})$ columns. Several studies on the characterization of wood extractives show that capillary GC is by far the most convenient and comprehensive technique available for separating the individual components in wood extractives (Vasconcelos et al., 2000; Fernandez et al., 2001). To identify the triterpenes and sterols from hexanic extract of $C$. exsucca, 26 authentic standards were used. These standards were obtained from several plant species, which were studied in our laboratory. In Table III are summarized the HRGC results of the sterols and triterpenes extracted and identified. These structures were unequivocally confirmed by coinjection of authentic standards and identified by relative retention value.

HPLC-ESI-MS represents the combination of a high-resolution separation system with a powerful detection/characterization technique, which has been successfully applied to the determination of compounds present in material from a variety of natural product source. A specific application of HPLC-ESI-MS natural product mixture analysis is the procedure known as dereplication. This process is rapid, precise and efficient besides has become one of the key processes for maintaining samples from natural source (Strege, 1999). Lin et al. (2000) utilized the HPLC-ESI-MS technique to detect the presence flavonoids in red clover.

TABLE IV - Flavonoids identified by HPLC-ESI-MS in ethanolic extract of Chresta exsucca

\begin{tabular}{lccc}
\hline Standards & $\mathrm{Rt}^{(\mathrm{min})^{\mathrm{a}}}$ & {$[\mathrm{M}-\mathrm{H}]^{-}(\mathrm{m} / \mathrm{z})^{\mathrm{b}}$} & Present flavonoids $^{\mathrm{a}}$ \\
\hline Apigenin & 16.86 & 269 & + \\
Luteolin & 16.22 & 285 & + \\
Genkwanin & 18.80 & 283 & + \\
Crysoeriol & 16.99 & 299 & + \\
Velutin & 18.74 & 313 & + \\
Kaempferol & 16.05 & 285 & - \\
Tiliroside & 15.53 & 579 & + \\
Luteolin 3'-O- $\beta$-D-glucopyranoside & 15.04 & 447 & + \\
Luteolin 4'-O- $\beta$-D-glucopyranoside & 13.51 & 447 & + \\
Luteolin 7-O- $\beta$-D-glucopyranoside & 9.17 & 447 & + \\
Vicenin-2 & 11.37 & 593 & + \\
\hline
\end{tabular}

$\mathrm{Rt}^{\mathrm{a}}=$ retention time values; ${ }^{\mathrm{b}}[\mathrm{M}-\mathrm{H}]^{-}=$molecular íon; $+=$presente flavonoids; - = compound not detected 
In order to verify the correct identification of the present flavonoids in the ethanolic extract of $C$. exsucca, 11 standards, all obtained from C. scapigera (Schinor, 2004), were used. Standard solutions of flavonoids were chromatographed to determine their retention times and MS data for comparison with the chromatograms of the plant extract. The results are showed in the Table IV.

Thus, the chemical composition of hexanic and ethanolic extract from C. exsucca could be determined without the need of isolation and purification processes of compounds through classical phytochemistry, which involves methods that are both costly and time-consuming. Steroids, triterpenes and flavonoids were identified in crude extracts of $C$. exsucca. Some of these compounds showed to be active against microorganisms (protozoal, bacteria and fungi) as reported previously by the literature (Salvador et al., 2004; Schinor et al., 2004; Taleb-Contini et al., 2003; Pena et al., 2001). However, further biological studies should be performed, including in vitro and in vivo investigations, as well as to evaluation of the toxicity, looking toward a clinical employment of these bioactive natural products.

\section{CONCLUSION}

Crude extracts of $C$. exsucca showed trypanocidal, leishmanicidal and antibacterial in vitro activities. The chemical composition of hexanic and ethanolic extracts was determined using HRGC and HPLC-ESI-MS chromatographic techniques. Steroids, triterpenes and flavonoids were identified.

\section{ACKNOWLEDGEMENT}

We wish to thank Prof. Dr. Walter Vichnewski for the plant collected and Prof. Dr. João Semir for plant identification. This work was supported by FAPESP (Fundação de Amparo à Pesquisa do Estado de São PauloBrazil), CNPq (Conselho Nacional de Desenvolvimento Científico e Tecnológico-Brazil) and CAPES (Coordenação de Aperfeiçoamento de Pessoal de N/ivel SuperiorBrazil).

\section{RESUMO}

\section{Atividades biológicas e composição química dos extratos brutos de Chresta exsucca}

As atividades tripanocida, leishmanicida, antibacteriana e antifungica dos extratos brutos de Chresta exsucca foram investigadas. Formas tripomastigotas do Trypanosoma cruzi, formas amastigotas de Leishmania amazonensis e vinte cepas de microrganismos, incluindo bactérias Gram-positivas, Gram-negativas e leveduras, foram utilizadas nos ensaios biológicos. Os melhores resultados foram obtidos para a atividade leishmanicida. A composição química dos extratos hexânicos e etanólicos dessa espécie foi determinada empregando-se técnicas cromatográficas como HRGC e HPLC-ESI-MS, respectivamente. Esteróides, triterpenos e flavonóides foram identificados.

UNITERMOS: Chresta exsucca. Asteraceae. Atividades biológicas. HRGC. HPLC-ESI-MS.

\section{REFERENCES}

ARAYA, J.E.; NEIRA, I., SILVA, S.; MORTARA, R.A.; MANQUE, P.; CORDERO, E.; SAGUA, H.; LOYOLA, A.; BÓRQUEZ, J.; MORALES, G.; GONZÁLEZ, J. Diterpenoids from Azorella compacta (Umbelliferae) active on Trypanosoma cruzi. Mem. Inst. Oswaldo Cruz, v. 98, p. 413-418, 2003.

BARATA, L.E.S.; SANTOS, L.S.; FERRI, P.H.; PHILLIPSON, J.D.; PAINE, A., CROFT, S.L. Antileishmanial activity of neolignans from Virola species and synthetic analogues. Phytochemistry, v. 55, p. 589-595, 2000.

BRENER, Z. Therapeutic activity on criterion of cure on mice experimentally infected with Trypanosoma cruzi. Rev. Inst. Med. Trop. São Paulo, v. 4, p. 389-396, 1962.

COLE, M.D. Key antifungal, antibacterial and ant-insect assays - a critical review. Biochem. Syst. Ecol., v. 22, p. 837-856, 1994.

COURA, J.R.; CASTRO, S.L. A critical review on Chagas disease chemotherapy. Mem. Inst. Oswaldo Cruz, v. 97, p. 3-24, 2002.

FERNANDEZ, M.P.; WATSON, P.A.; BREUIL, C. Gas chromatography-mass spectrometry methods for the simultaneous determination of wood extractive compounds in quaking aspen.J. Chromatogr. A, v. 922, p. 225-233, 2001.

GROVE, D.C.; RANDALL, W.A. Assay methods of antibiotics: a laboratory manual. New York: Medical Encyclopedia Inc., 1955. 80 p. (Antibiotics monographs, 02). 
KARAMAN, I.; SAHIN, F.; GÜLLÜCE, M.; ÖGÜTÇÜ, H.; SENGÜL, M.;ADIGÜZEL, A. Antimicrobal activity of aqueous and methanol extracts of Juniperus oxycedrus L. J. Ethnopharmacol., v. 85, p. 231-235, 2003.

KAYSER, O.; KINDERLEN, A.F.; CROFT, S.L. Natural products as potential antiparasitic drugs. Parasitol. Res., v. 90, p. 55-62, 2003a.

KAYSER, O.; KINDERLEN, A.F.; CROFT, S.L. Antileishmanial activity of two gama-pyrones from Podolepsis hieracioides (Asteraceae). Acta Trop., v. 86, p. 105-107,2003b.

LIN, L.Z.; HE, X.G.; LINDENMAIER, M.; YANG, J.; CLEARY, M.; QIU, S.X.; CORDELL, G.A. LC-ESIMS study of the flavonoid glycoside malonates of red clover (Trifolium pratense). J. Agric. Food Chem., v. 48, p. 354-365, 2000.

MACLEISH, N.F.F. Revision of Chresta and Pycnocephalum (Compositae: Vernonieae). Syst. Bot., v. 10, p. 459-470, 1985.

MONCAYO, A. Chagas disease: current epidemiological trends after the interruption of vectorial and transfusional transmission in the Southern Cone Contries. Mem. Inst. Oswaldo Cruz, v. 98, p. 577-591, 2003.

MOSMANN, T. Rapid colorimetric assay for cellular growth and survival: application to proliferation and cytotoxicity assays. J. Imm. Methods, v. 65, p. 55-63, 1983.

\section{NATIONAL COMMITTEE FOR CLINICAL} LABORATORY STANDARDS. Methods for dilution in antimicrobial susceptibility tests. Approved standard M2-A5. National Committee for Clinical Laboratory Standards, Villanova, PA, 1983.

NEWMAN, D.J.; CRAGG, G.M.; SNADER, K.M. Natural products as sources of new drug over the period 19812002. J. Nat. Prod., v. 66, p. 1022-1037, 2003.

OKEKE, M.I.; IROEGBU, C.U.; EZE, E.N.; OKOLI, A.S.; ESIMONE, C.O. Evaluation of extracts of the roots of Landolphia oweeunce root for antibacterial activity. $J$. Ethnopharmacol., v. 78, p. 119-127, 2001.
OUMZIL, H.; GHOULAMI, S.; RHAJAOUI, M.; ILIDRISSI, A.; FKIH-TETOUANI, S.; FAID, M.; BENJOUAD, A. Antibacterial and antifungal activity of essential oils of Mentha suaveolens. Phytother. Res., v. 16, p. 727-731, 2002.

PENNA, C.; MARINO, S.; VIVOT, E.; CRUAÑES, M.C.; MUÑOZ, J.D.; CRUAÑES, J.; FERRARO, G.; GUTKIND, G.; MARTINO, V. Antimicrobial activity of Argentine plants used in the treatment of infectious diseases. Isolation of active compounds from Sebastiania brasiliensis. J. Ethnopharmacol., v. 77, p. 37-40, 2001.

PETERS, W. The evolution of tafenoquine-antimalarial for a new millennium. J. R. Soc. Med., v. 92, p. 345-352, 1999.

PRAL, E.M.F.; MOITINHO, M.L.R.; BALANCO, J.M.F.; TEIXEIRA, V.R.; MILDER, R.V.; ALFIERI, S.C. Growth phase and medium $\mathrm{pH}$ modulate the expression of proteinase activities and the development of megasomes in axenically cultivated Leishmania (Leishmania) amazonensis amastigote-like organisms. J. Parasitol., v. 89, p. 35-43, 2003.

ROBINSON, H. Generic and subtribal classification of American Vernonieae. Washington: Smithsonian Institution Press, p. 9-12, 1999.

SALVADOR, M.J.; ZUCCHI, O.L.A.D.; CANDIDO, R.C.; ITO, I.Y.; DIAS, D.A. In vitro antimicrobial activity of crude extracts and isolated constituents of Alternanthera maritima Amaranthaceae). Pharm. Biol., v. 42, p. 499-505, 2004.

SCHINOR, E.C. Estudo fitoquímico e atividades biológicas de duas espécies de Chresta (Vernonieae Asteraceae). Ribeirão Preto, 2003, 181f. [Tese de Doutorado. Faculdade de Filosofia, Ciências e Letras de Ribeirão Preto. Universidade de São Paulo].

SCHINOR, E.C.; SALVADOR, M.J.; ALBUQUERQUE, S.; ITO, I.Y.; DIAS, D.A. Trypanocidal and antimicrobial activities of Moquinia kingii. Phytomedicine, v. 11, p. 224-229, 2004.

STREGE, M.A. High-performance liquid chromatographyelectrospay ionization mass spectrometric analyses for the integration of natural products with modern highthroughput screening. J. Chromatogr. B, v. 725, p. $67-78,1999$. 
TAKEARA, R.; ALBUQUERQUE, S.; LOPES, N.L.; LOPES, J.L.C. Trypanocidal activity of Lychnophora staavioides Mart, (Vernonieae, Asteraceae). Phytomedicine, v. 10, p. 490-493, 2003.

TALEB-CONTINI, S.H.; SALVADOR, M.J.; BALANCO, J.M.F.; ALBUQUERQUE, S.; OLIVEIRA, D.C.R. Antiprotozoal effect of crude extracts and flavonoids from Chromolaena hirsuta (Asteraceae). Phytother. Res., v. 18, p. 250-254, 2004.

THAKUR, C.P.; SINGH, R.K.; HASSAU, S.M.; KUMAR, R.; NARAIN, S.; KUMAR, A. Amphotericin $\mathrm{B}$ deoxycholate treatment of visceral leishmaniasis with newer modes of administration and precaution: a study of 938 cases. Trans. R. Soc. Trop. Med. Hyg., v. 93, p. 319, 1999.

TRUITI, M.D.T.; SARRAGIOTTO, M.H.; ABREU FILHO, B.A.; NAKAMURA, C.V.; DIAS FILHO, B.P. In vitro antibacterial activity of a 7-O- $\beta$-D-glucopyranosylnutanocoumarin from Chaptalia nutans (Asteraceae). Mem. Inst. Oswaldo Cruz, v. 98, p. 283-286, 2003.
VASCONCELOS, E.C.; VILEGAS, J.H.Y.; LANÇAS, F.M. Comparison of extraction and clean-up methods for the analysis of friedelan-3-ol and friedelin from leaves of Maytenus aquifolium Martius (Celastraceae). Phytochem. Anal., v. 11, p. 247-250, 2000.

WHO. Control of the leishmanioses. Report of a WHO Expert Committee. Technical Report Series 793. WHO: Geneva, 1990.

WHO. Control of Chagas disease. Report of a WHO Expert Committee. Technical Report Series 881. WHO: Geneva, 1991.

WHO. Special Programme for Research and Training in Tropical Disease (TDR). Natural products for parasitic diseases. TDR News, Geneva, v. 62, p. 4, 2000.

Recebido para publicação em 21 de janeiro de 2005. Aceito para publicação em 29 de julho de 2005. 